\title{
Bortezomib and Thalidomide Treatment Results in Newly Diagnosed Transplant-Ineligible Multiple Myeloma Patients are Comparable in Long-Term Follow-Up
}

\section{Výsledky léčby bortezomibem a thalidomidem u nově diagnostikovaných netransplantovaných pacientů s mnohočetným myelomem jsou srovnatelné}

\author{
Stork M. ${ }^{1}$, Sandecka V. ${ }^{1}$, Boichuk I. ${ }^{1}$, Adam Z. ${ }^{1}$, Krejci M. ${ }^{1}$, Brozova L. ${ }^{2}$, Sevcikova S. ${ }^{3}$, Pour L. ${ }^{1}$ \\ 'Department of Internal Medicine, Hematology and Oncology, University Hospital Brno \\ ${ }^{2}$ Institute of Biostatistics and Analyses, Faculty of Medicine, Masaryk University, Brno \\ ${ }^{3}$ Babak Myeloma Group, Department of Pathological Physiology, Faculty of Medicine, Masaryk University, Brno
}

\begin{abstract}
Summary
Background: Thalidomide- and bortezomib-containing regimens are widely used for transplant-ineligible newly diagnosed multiple myeloma patients. The aim of this study was to analyse the efficiency of thalidomide- or bortezomib-based regimens in long-term follow-up. Materials and methods: From 2008 to 2012, 142 transplant-ineligible newly diagnosed multiple myeloma patients were analysed retrospectively. Bortezomib was administered at the standard dosing of $1.3 \mathrm{mg} / \mathrm{m}^{2}$ weekly, and thalidomide was administered at a daily dose of $100 \mathrm{mg}$. Both drugs were combined with cyclophosphamide and dexamethasone. A total of 95 patients were treated with thalidomide and 47 with bortezomib. A median four cycles of treatment were administered in both groups. Results: In the thalidomide group, the overall response rate was $60.6 \%$, the median progression-free survival (PFS) was 10.3 months $(95 \% \mathrm{Cl} 7.4-13.2)$ and the median overall survival (OS) was 35.1 months (95\% Cl 23.9-46.3). In the bortezomib group, the overall response rate was $51.1 \%$, the median PFS was 11.9 months $(95 \% \mathrm{Cl} 8.8-15)$ and the median OS was 25.4 months $(95 \% \mathrm{Cl}$ 9.3-41.6). There was a statistically significant difference in OS ( $p=0.027)$, favouring the cyclophosphamide/thalidomide/dexamethasone group, but the response rates and PFS intervals were not significantly different between both groups. The median follow-up in the thalidomide group was 35.1 months ( $95 \% \mathrm{Cl} 0.2-95.9$ ) compared to 25.1 months $(95 \% \mathrm{Cl} 0.4-60.6)$ in the bortezomib group $(p=0.004)$. The incidence of serious adverse events was comparable in both groups. Conclusion: In conclusion, the results of bortezomib treatment are comparable to thalidomide treatment under conditions of short administration. According to other clinical trials, long-term bortezomib treatment provides an additional advantage for PFS and OS.
\end{abstract}

Key words

bortezomib - thalidomide - multiple myeloma - primotherapy
The authors would like to thank all the patients and their caregivers for participating in this study.

Autoři děkuji všem pacientům a jejich ošetřovatelưm za účast v této studii.

The authors declare they have no potential conflicts of interest concerning drugs, products, or services used in the study.

Autoři deklarují, že $v$ souvislosti $s$ predmětem studie nemají žádné komerční zájmy.

The Editorial Board declares that the manuscript met the ICMJE recommendation for biomedical papers.

Redakční rada potvrzuje, že rukopis práce splnil ICMJE kritéria pro publikace zasílané do biomedicínských časopisů.

MUDr. Viera Sandecká, Ph.D. Department of Internal Medicine Hematology and Oncology University Hospital

Jihlavska 20

62500 Brno

e-mail: sandecka.viera@fnbrno.cz

Submitted/Obdrženo: 11. 7. 2019

Accepted/Prijato: 17. 9. 2019

doi: 10.14735/amko2019445 


\begin{abstract}
Souhrn
Východiska: Režimy obsahující thalidomid a bortezomib jsou široce používané pro nově diagnostikované pacienty s mnohočetným myelomem neschopné autologní transplantace kostní dřeně. Cílem této práce bylo srovnat dlouhodobou efektivitu thalidomidového a bortezomibového režimu v dlouhém sledování. Metody: Celkově bylo mezi roky 2008 a 2012 retrospektivně analyzováno 142 pacientů s nově diagnostikovaným mnohočetným myelomem neschopných autologní transplantace. Bortezomib byl podáván ve standardním dávkování $1,3 \mathrm{mg} / \mathrm{m}^{2} 1 \mathrm{krát} \mathrm{týdně}$ a thalidomid v denní dávce $100 \mathrm{mg}$. Oba léky byly kombinované s cyklofosfamidem a dexamethasonem. Celkem 95 pacientů bylo léčeno thalidomidovým režimem a 47 bortezomibovým režimem. V obou skupinách byl medián čtyři cykly léčby. Výsledky: Ve skupině s thalidomidem byla celková četnost odpovědí 60,6 \%, medián přežití bez progrese (progression-free survival - PFS) byl 10,3 měsíce $(95 \% \mathrm{Cl} 7,4-13,2)$ a medián celkového přežití (overall survival - OS) 35,1 měsíce $(95 \%$ Cl $23,9-46,3)$. Ve skupině s bortezomibem byla celková četnost odpovědí $51,1 \%$, medián PFS 11,9 měsíce $(95 \% \mathrm{Cl} 8,8-15)$ a medián OS 25,4 měsíce $(95 \% \mathrm{Cl} 9,3-41,6)$. Délka OS byla statisticky signifikantně delší u skupiny léčené thalidomidem $(p=0,027)$, ale počet dosažených léčebných odpovědí a interval PFS byl v obou skupinách srovnatelný. Medián času sledování byl ve skupině léčené thalidomidem 35,1 měsíce $(95 \% \mathrm{Cl} 0,2-95,9)$ a ve skupině léčené bortezomibem 25,1 měsíce $(95 \% \mathrm{Cl} 0,4-60,6)$, $\mathrm{p}=0,004$. Výskyt závažných nežádoucích účinků léčby byl srovnatelný v obou skupinách. Závěr: Za předpokladu krátkého trvání léčby jsou výsledky bortezomibového režimu srovnatelné s režimem thalidomidovým. Vzhledem k výsledkům ostatních klinických studií je zřejmé, že dlouhá doba léčby bortezomibem je spjata s delším přežitím bez progrese a též i prežitím celkovým.
\end{abstract}

Klíčová slova

bortezomib - thalidomid - mnohočetný myelom - primoterapie

\section{Introduction}

Multiple myeloma $(\mathrm{MM})$ is the second most common haematological malignancy. The incidence of MM in the Czech Republic is $4.8 / 100,000$. The median age at diagnosis is 65 , but only $2 \%$ of the patients are younger than 40 years of age [1]. While $M M$ is a hard disease to treat, the development of new drugs has changed treatment outcomes fundamentally. The use of bortezomib and thalidomide at the start of the new millennium was a significant improvement in the field of MM treatment [2].

Thalidomide, a glutamic acid derivative, is the first of the immunomodulatory drugs used in MM treatment. Thalidomide efficiency was first documented in relapsed MM patients in 1999 [3]. Thalidomide efficiency in primotherapy was confirmed in the meta-analysis of six clinical trials in newly diagnosed MM (NDMM) patients ineligible for autologous stem cell transplantation (ASCT). Thalidomide showed a much better response rate and longer survival intervals than the conventional melphalan prednisone regimen (overall response rate (ORR) in the $1^{\text {st }}$ year: 59 vs. $37 \%, p<0.001$, progression-free survival (PFS) median 21.8 vs. 14.5 months, $p=0.004$ ) [4]. Limiting toxicity was represented mainly by sensomotoric polyneuropathy, thromboembolic complications, cytopenia, constipation or cognitive disorders [5].

Bortezomib is a reversible proteasome inhibitor. Bortezomib efficiency in trans- plant-ineligible NDMM patients was first analysed in the VISTA trial. Bortezomib showed significantly better results than the standard melphalan prednisone treatment (ORR 71 vs. $31 \%, \mathrm{p}<0.001$, median time to progression [TTP] $24.4 \mathrm{vs.}$ 16.6 months, median overall survival [OS] 56.4 vs. 43.1 months, $p<0.001$ ) [6]. The most serious and unpredictable adverse effect of bortezomib is polyneuropathy. Other bortezomib side effects are herpetic infections, diarrhoea and thrombocytopenia, only rarely accompanied by bleeding [7].

The depth of response in primotherapy is crucial for response duration and OS. Thus, the choice of the most effective treatment regimen in NDMM patients is a major factor affecting the entire prognosis [6-9]. Combined regimens with thalidomide and alkylators showed significant efficiency in ASCT-ineligible NDMM patients [4-10]. However, the superiority of bortezomib-based treatment regimens in NDMM patients was later demonstrated in the meta-analyses of clinical trials $[11,12]$.

In the Czech Republic, the melphalan prednisone regimen was administered as the standard of induction treatment in ASCT-ineligible NDMM patients until 2008. Thalidomide-based therapy has been reimbursed since 2008 and bortezomib-based therapy since 2010 .

This analysis compares the therapeutic efficacy of the induction regimens composed of cyclophosphamide, thalidomide and dexamethasone (CTD) vs. cy- clophosphamide bortezomib (Velcade ${ }^{\circledR}$ ), and dexamethasone (CVD) in the therapy of ASCT-ineligible NDMM patients.

\section{Patients and methods \\ Data collection}

All the acquired data were recorded in the Registry of Monoclonal Gammopathies of the Czech Myeloma Group. The data were primarily analysed in June 2013; after the follow-up period, the survival intervals were updated in 2018. All the participants provided written informed consent to the inclusion of their data in the Registry of Monoclonal Gammopathies. These consent forms were approved by the institutional ethics board in accordance with the latest Declaration of Helsinki.

\section{Patients' characteristics}

We retrospectively analysed 142 NDMM patients ineligible for ASCT. All the patients were treated at the Department of Internal Medicine, Hematology and Oncology, University Hospital Brno, Czech Republic, between 2008 and 2012. The median follow-up of the patients treated with thalidomide was 35.1 months (range 0.2-95.9) and for the patients treated with bortezomib, 25.1 months (range 0.4-60.6). The patients' characteristics are summarised in Tab. 1.

\section{Administered treatment}

All the patients were treated according to the investigator's decision with the 
best available treatment. In the first time period (from 2008 to 2010), the patients were treated with thalidomide and in the second period (from 2010 to 2012), the patients were treated with bortezomib, according to the Czech healthcare insurance rules. Our treatment options were limited by 'stop rules', established by health insurance in 2002-2015. This means that the treatment was stopped when the patients did not achieve at least a partial response (PR) after four treatment cycles, and that the treatment was stopped when the patient achieved a complete response.

In the CTD arm, the dosing protocol was as follows: cyclophosphamide $50 \mathrm{mg}$ orally daily; thalidomide $100 \mathrm{mg}$ daily; dexamethasone $20 \mathrm{mg}$ orally on days 1-4 and 15-18 of a twenty-eightday cycle. All the patients had thromboembolic prophylaxis with low molecular weight heparin. Omeprazole ( $20 \mathrm{mg} /$ day) was administered as a corticosteroid-induced gastropathy prophylaxis during corticosteroid therapy. In patients with a high risk of infection (e.g. elderly and frail patients, patients with frequent infections), antibiotic prophylaxis with co-trimoxazole ( $480 \mathrm{mg} /$ day) was administered according to the investigator's decision.

In the CVD arm, the subsequent dosing schedule was as follows: cyclophosphamide $50 \mathrm{mg}$ orally daily; bortezomib $1.3 \mathrm{mg} / \mathrm{m}^{2}$ intravenously on days 1,8 , 15 and 22 of a twenty-eight-day cycle; dexamethasone $20 \mathrm{mg}$ orally on days 1-4 and 15-18 of a twenty-eight-day cycle. Omeprazole and co-trimoxazole were used as described above. Acyclovir ( $200 \mathrm{mg} /$ day) was used in all patients as a herpetic infection prophylaxis. In bortezomib intravenous administration, prehydratation with $500 \mathrm{~mL}$ of physiological saline solution and posthydratation with $100-250 \mathrm{~mL}$ of physiological saline solution were used.

Response and adverse event

assessment

The endpoint of this analysis was the CTD and CVD regimen treatment response and survival interval comparison. The response was assessed after treatment withdrawal, a minimum of

Tab. 1. Patients demographic and baseline characteristics.

\begin{tabular}{|c|c|c|c|}
\hline Basic characteristics $(N=142)$ & CTD (N = 95) & CVD (N = 47) & p-value ${ }^{1}$ \\
\hline Sex, N (\%) & $\mathbf{N}=95$ & $N=47$ & \\
\hline men & $51(53.6 \%)$ & $29(61.7 \%)$ & \multirow{2}{*}{0.376} \\
\hline woman & $44(46.3 \%)$ & $18(38.3 \%)$ & \\
\hline Age & $\mathrm{N}=95$ & $\mathbf{N}=\mathbf{4 7}$ & \\
\hline median (min-max) & $68(51-85)$ & $72(60-90)$ & 0.001 \\
\hline Follow-up (months) & $\mathrm{N}=95$ & $\mathbf{N}=\mathbf{4 7}$ & \\
\hline median (min-max) & $35.1(0.2-95.9)$ & $25.1(0.4-60.6)$ & 0.004 \\
\hline Durie Salmon stage, N (\%) & $\mathrm{N}=95$ & $\mathrm{~N}=47$ & \\
\hline 1 & $21(22.1 \%)$ & $11(23.4 \%)$ & \multirow{3}{*}{0.904} \\
\hline II & $14(14.7 \%)$ & $8(17.0 \%)$ & \\
\hline III & $60(63.2 \%)$ & $28(59.6 \%)$ & \\
\hline Durie Salmon Sub-stage, N (\%) & $\mathrm{N}=95$ & $N=47$ & \multirow{4}{*}{0.178} \\
\hline A & $80(84.2 \%)$ & $35(74.5 \%)$ & \\
\hline B & $15(15.7 \%)$ & $12(25.5 \%)$ & \\
\hline ISS stage, N (\%) & $\mathbf{N}=93$ & $N=46$ & \\
\hline 1 & $36(38.7 \%)$ & $11(23.9 \%)$ & \multirow{3}{*}{0.192} \\
\hline 2 & $28(30.1 \%)$ & $19(41.3 \%)$ & \\
\hline 3 & $29(31.2 \%)$ & $16(34.8 \%)$ & \\
\hline Performance status (ECOG), N (\%) & $\mathbf{N}=\mathbf{8 0}$ & $N=46$ & \multirow{4}{*}{0.111} \\
\hline $0-1$ & $58(72.5 \%)$ & $25(54.3 \%)$ & \\
\hline 2 & $14(17.5 \%)$ & $12(26.1 \%)$ & \\
\hline $3-4$ & $8(10.0 \%)$ & $9(19.6 \%)$ & \\
\hline Myeloma type, N (\%) & $N=95$ & $N=47$ & \multirow{5}{*}{0.005} \\
\hline $\lg G$ & $56(58.9 \%)$ & $29(61.7 \%)$ & \\
\hline $\lg A$ & $26(27.4 \%)$ & $4(8.5 \%)$ & \\
\hline LC only & $9(9.5 \%)$ & $13(27.7 \%)$ & \\
\hline other $^{2}$ & $4(4.3 \%)$ & $1(2.1 \%)$ & \\
\hline FLC type, N (\%) & $\mathbf{N}=93$ & $\mathbf{N}=\mathbf{4 7}$ & \multirow{3}{*}{0.591} \\
\hline Kappa & $56(60.2 \%)$ & $26(55.3 \%)$ & \\
\hline Lambda & $37(39.8 \%)$ & $21(44.7 \%)$ & \\
\hline
\end{tabular}

Data described by count (relative frequencies) and median (min-max).

${ }^{1} \mathrm{p}$-value of Fisher's exact test or Mann-Whitney $U$ test

${ }^{2}$ other includes IgM, nonsecretory or biclonal M-protein type

CTD - thalidomide, CVD - bortezomib, ISS - International Staging System, ECOG Eastern Cooperative Oncology Group, lg - immunoglobulin, LC - light chain, FLC free light chains

60 days after the last bortezomib administration. The response was assessed according to the current International Myeloma Working Group criteria [13].
Thalidomide and bortezomib treatment toxicity were also analysed. Adverse events (AEs) were graded using the National Cancer Institute Common Terminology Criteria for Adverse Events 
Tab. 2. Treatment response for CTD and CVD in NDMM patients.

\begin{tabular}{|c|c|c|c|}
\hline Treatment response, $\mathbf{N}(\%)$ & CTD (N = 94) & CVD $(N=47)$ & p-value ${ }^{1}$ \\
\hline complete response & $14(14.9 \%)$ & $4(8.5 \%)$ & \multirow{6}{*}{0.658} \\
\hline very good partial response & $23(24.5 \%)$ & $11(23.4 \%)$ & \\
\hline partial response & $20(21.3 \%)$ & $9(19.1 \%)$ & \\
\hline minimal response & $4(4.3 \%)$ & $5(10.6 \%)$ & \\
\hline stable disease & $5(5.3 \%)$ & $2(4.3 \%)$ & \\
\hline progressive disease & $28(29.8 \%)$ & $16(34.0 \%)$ & \\
\hline overall response rate $(\mathrm{PR}+)$ & $57(60.6 \%)$ & $24(51.1 \%)$ & 0.279 \\
\hline
\end{tabular}

version 5.0 [14]. Safety was evaluated throughout the treatment and during the long-term follow-up.

\section{Statistical methods}

The patients' characteristics were described using absolute and relative frequencies or median (minimum-maximum). For comparison of the treatment groups, Fisher's exact test or Pearson's chi-square test was adopted. OS, PFS, TTP and duration of response (DOR) were assessed using the Kaplan-Meier methodology. The log-rank test was used to estimate the statistical significance of the difference between the curves. P-values of less than 0.05 were considered statistically significant (all tests two-sided). Analysis was performed in the SPSS software and software $R$.

\section{Results}

Patients and treatment

Altogether, 95 patients were treated with CTD and 47 with CVD. The median age at diagnosis was 68 (range 51-85) in the CTD arm and 72 (range 60-90) in the CVD arm, the difference in age was statistically significant $(p=0.001)$. There were significantly more patients with Bence Jones (BJ) type myeloma in the CVD arm (27.7 vs. 9.5\%) and more immunoglobulin A ( $\lg \mathrm{A})$ myeloma patients in the CTD arm (27.4 vs. 7.5), $\mathrm{p}=0.006$. The proportion of other MM types, Durie Salmon (DS), International Staging System (ISS) stage or Eastern Cooperative Oncology Group (ECOG) performance status was comparable in both groups. The median of administered treatment cycles was four (range one to ten) in the CTD arm and four (range one to thirteen) in the CVD arm. The median follow-up was significantly longer in the CTD arm (35.1 months (95\% Cl 0.2-95.9)) when compared to the CVD arm (25.1 months (95\% Cl 0.4-60.6), $\mathrm{p}=0.004)$. The thalidomide dose was reduced due to toxicity in $33.7 \%$ (32/95) of the patients and the bortezomib dose in $25.5 \%$ (12/47) of the patients, respectively.

\section{Response to treatment}

Treatment response was evaluable in $99.2 \%(141 / 142)$ of the patients.

PR or better response (ORR) was achieved in $60.6 \%$ (57/94) of the patients in the CTD arm compared to $51.1 \%(24 / 47)$ in the CVD arm. This difference was not statistically significant $(p=0.279)$.

Complete response was achieved in $14.9 \%(14 / 94)$ of the patients in the CTD arm, compared to $8.5 \%$ (4/47) of the patients in the CVD arm. Very good PR was achieved in $24.5 \%$ (23/94) of the patients in the CTD arm, compared to $23.4 \%$ $(11 / 47)$ of the patients in the CVD arm, PR in 21.3\% (20/94) in the CTD arm, compared to $19.1 \%(9 / 47)$ in the CVD arm. In total, $29.8 \%$ (28/94) of the patients in the CTD arm and $34.0 \%$ (16/47) of the patients in the CVD arm progressed during the treatment or within 60 days after treatment withdrawal. There was no significant difference in treatment responses in both arms $(p=0.658)$. The treatment responses are summarised in Tab. 2.

\section{Survival intervals}

The median PFS was 10.3 months (95\% Cl 7.4-13.2) in the CTD arm and 11.9 months (95\% Cl 8.8-15.0) in the CVD arm $(p=0.824)$; median DOR 20.2 months (95\% Cl 15.1-25.3) in the CTD arm and 17.0 months $(95 \% \mathrm{Cl} 8.9-25.1)$ in the CVD arm $(p=0.522)$, median TTP 12.0 months $(95 \% \mathrm{Cl} 7.6-16.3)$ in the CTD arm and 15.2 months $(95 \% \mathrm{Cl} 11.3-19.1)$ in the CVD arm $(p=0.107)$. All the previously mentioned survival intervals were not significantly different between the treatment groups. The median OS was significantly longer in the CTD arm, 35.1 months (95\% Cl 23.9-46.3) compared to 25.4 months $(95 \% \mathrm{Cl} 9.3-41.6)$ in the CVD arm ( $p=0.027)$. The survival intervals are concluded in Fig. 1A-D.

\section{Adverse events}

Serious toxicity (grades 3 and 4 according to the National Cancer Institute Common Terminology Criteria for Adverse Events criteria and polyneuropathy grade 2) was observed in 54.3\% $(77 / 142)$ of the patients. Serious toxicity in the CTD arm was experienced by $49.5 \%(47 / 95)$ of the patients and in $63.8 \%(30 / 47)$ of the patients in the CVD arm, respectively.

The most frequent non-haematologic adverse event was polyneuropathy. Polyneuropathy grade 1 occurred in $27.4 \%$ (26/95) of the patients in the CTD arm and in $6.4 \%(3 / 47)$ of the patients in the CVD arm, grade 2 occurred in $14.7 \%$ (14/95) of the patients in the CTD arm and in $17.0 \%$ (8/47) of the patients in the CVD arm. Grade 3 polyneuropathy was observed in $2.1 \%(2 / 95)$ of the patients in the CTD arm and in $2.1 \%(1 / 47)$ in the CVD arm, respectively. The incidence of polyneuropathy was significantly higher in the CTD $\operatorname{arm}(p=0.015)$. There was no incidence of polyneuropathy grade 4 in both arms.

The second most frequent non-haematologic adverse event was constipation. The incidence of mild (grade 1-2) constipation was higher in the CTD arm (40.0\% (38/95) vs. $17.0 \%$ (8/47), $p=0.012$ ). Severe constipation occurred only in $2.1 \%$ (2/95) of the patients in the CTD arm. 
A) Overall survival

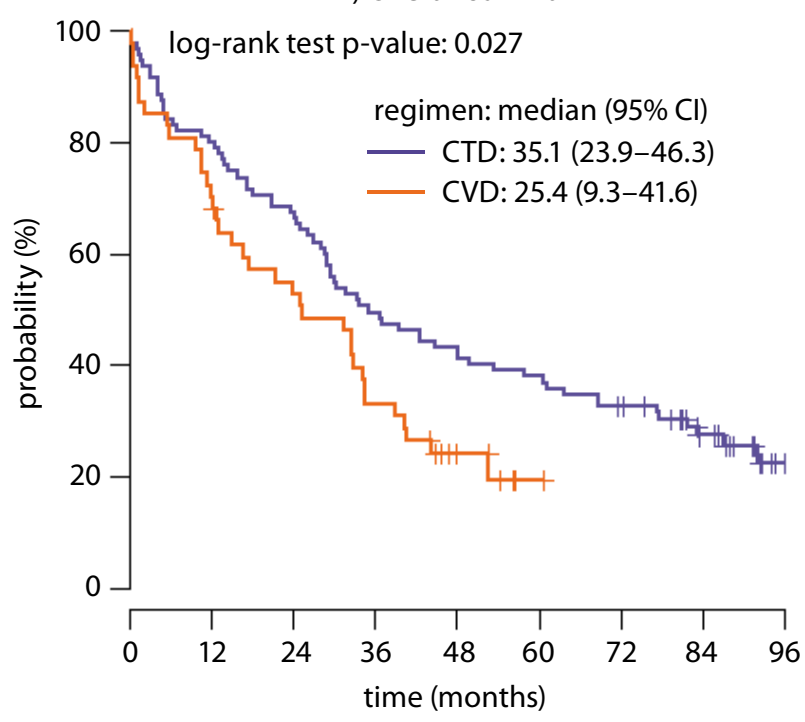

C) Time to progression

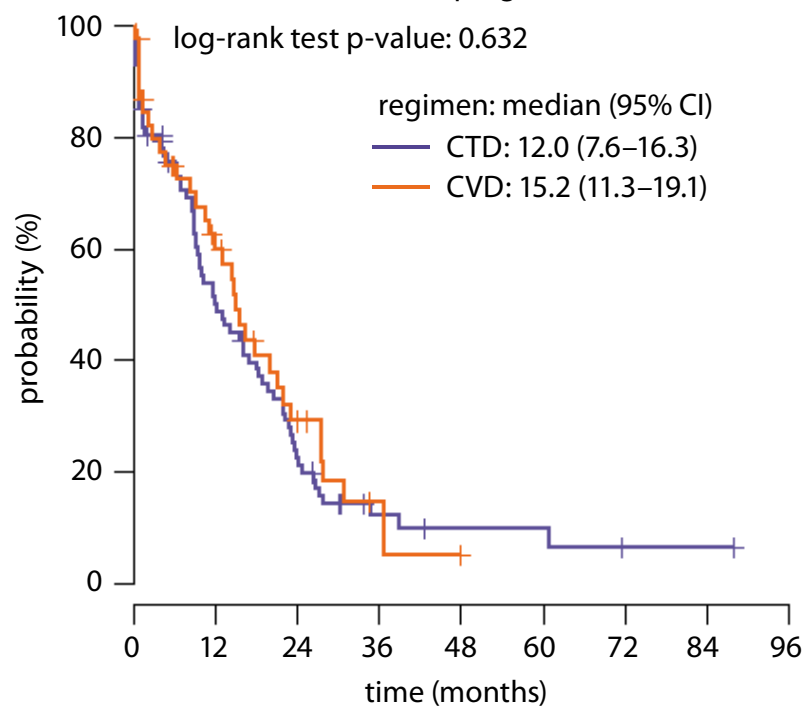

B) Progression-free survival

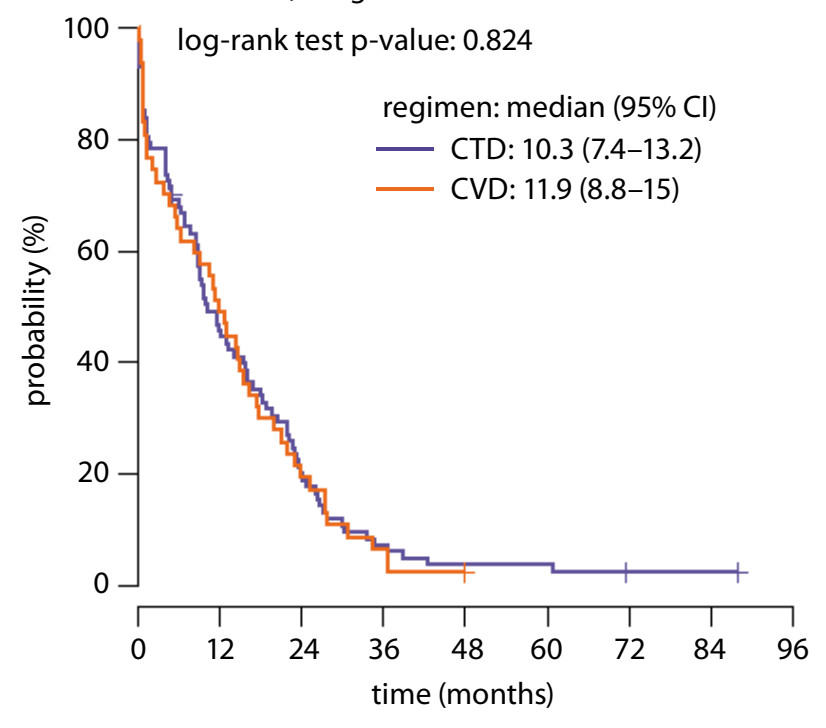

D) Duration of response

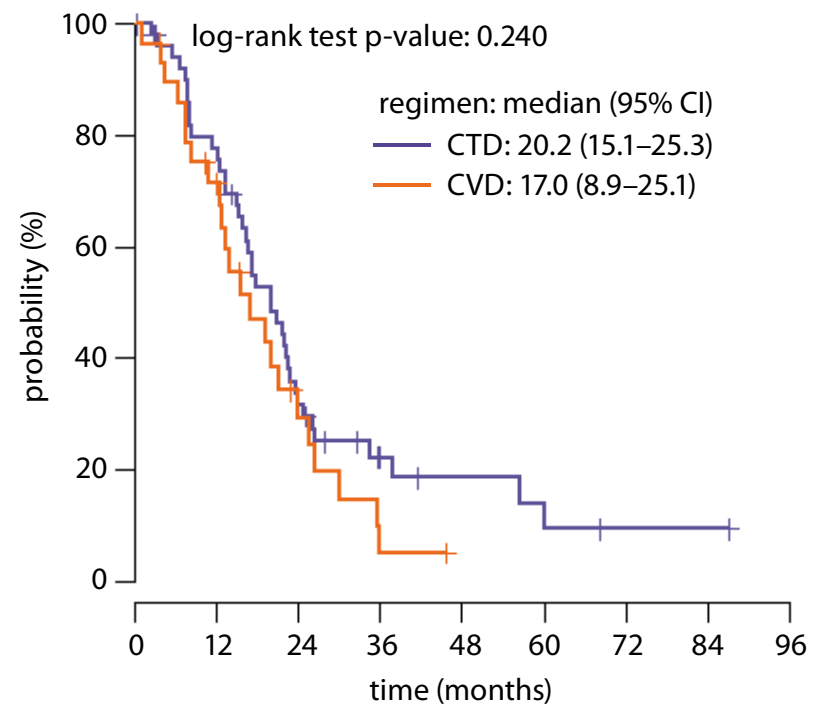

Fig. 1. Survival intervals in CTD and CVD groups ( $N=142$ treatment lines).

A. Overall survival in CTD and CVD treatment arms. B. Progression-free survival in CTD and CVD treatment arms. C. Time to progression in CTD and CVD treatment arms. D. Duration of response in CTD and CVD treatment arms.

CTD - thalidomide, CVD - bortezomib

The incidence of thromboembolic events was slightly higher in the CTD arm (8.4 vs. $4.2 \%$ ), but the difference was not statistically significant ( $p=0.288$ ).

Haematologic AEs were more frequent in the CVD arm, but were mostly mild (grade 1-2).

The most frequent was mild anaemia (CVD 72.3\% (34/47) vs. CTD 35.9\%
(36/95), $\mathrm{p}<0.001)$ and mild thrombocytopenia (CVD 51.1\% (24/47) vs. CTD $9.5 \%(9 / 95), p<0.001)$. The incidence of frequent or serious $\mathrm{AEs}$ is described in Tab. 3.

Dose reduction due to toxicity was necessary in $33.7 \%(32 / 95)$ of the patients in the CTD arm compared to $25.5 \%$ $(12 / 47)$ of the patients in the CVD arm.
Due to uncontrollable toxicity, treatment was withdrawn in $24.2 \%$ (23/95) of the patients in the CTD arm compared to $10.6 \%(5 / 47)$ of the patients in the CVD arm.

\section{Discussion}

In the last two decades, we have experienced enormous improvement in the 
Tab. 3. Adverse events in CTD and CVD treatment of newly diagnosed elderly multiple myeloma patients ( $N=142$ patients).

\begin{tabular}{|c|c|c|c|c|c|c|c|c|c|}
\hline \multirow{2}{*}{$\begin{array}{l}\text { Adverse events }^{1} \\
\text { Grade, } \mathrm{n}(\%)\end{array}$} & \multicolumn{4}{|c|}{ CTD (N = 95) } & \multicolumn{4}{|c|}{ CVD $(N=47)$} & \multirow[t]{2}{*}{$\mathbf{P}^{2}$} \\
\hline & 1 & 2 & 3 & 4 & 1 & 2 & 3 & 4 & \\
\hline neutropenia & $12(12.6)$ & $15(15.8)$ & $9(9.5)$ & $2(2.1)$ & $6(12.8)$ & $6(12.8)$ & $4(8.5)$ & $3(6.4)$ & 0.774 \\
\hline infection & - & $19(20.0)$ & $6(6.3)$ & $2(2.1)$ & $1(2.1)$ & $3(6.4)$ & $5(10.6)$ & $3(6.4)$ & 0.051 \\
\hline thrombosis/embolism & - & - & $7(7.4)$ & $1(1.1)$ & - & $1(2.1)$ & $1(2.1)$ & - & 0.288 \\
\hline anemia & $23(24.2)$ & $13(13.7)$ & $3(3.2)$ & - & $15(31.9)$ & $19(40.4)$ & $3(6.4)$ & - & $<0.001$ \\
\hline neuropathy & $26(27.4)$ & $14(14.7)$ & $2(2.1)$ & - & $3(6.4)$ & $8(17.0)$ & $1(2.1)$ & - & 0.015 \\
\hline constipation & $21(22.1)$ & $17(17.9)$ & $2(2.1)$ & - & $4(8.5)$ & $4(8.5)$ & - & - & 0.012 \\
\hline thrombocytopenia & $6(6.3)$ & $3(3.2)$ & - & $1(1.1)$ & $22(46.8)$ & $2(4.3)$ & - & $1(2.1)$ & $<0.001$ \\
\hline anorexia & $5(5.3)$ & $2(2.1)$ & - & - & $3(6.4)$ & $2(4.3)$ & $1(2.1)$ & - & 0.453 \\
\hline nausea & $7(7.4)$ & $2(2.1)$ & - & - & 5 (10.6) & $4(8.5)$ & - & - & 0.191 \\
\hline diarrhea & $5(5.3)$ & $1(1.1)$ & - & - & $2(4.3)$ & $4(8.5)$ & - & - & 0.104 \\
\hline \multicolumn{10}{|c|}{$\begin{array}{l}1 \text { Sorted by total frequency of grade } \geq 3 \text {; dash shown in case of zero frequency. } \\
{ }^{2} \text { p-value of Fisher's exact test. } \\
\text { CTD - thalidomide, CVD - bortezomib }\end{array}$} \\
\hline
\end{tabular}

treatment of NDMM patients ineligible for ASCT [2]. Thalidomide-based regimens achieved a significant improvement of treatment results compared to conventional chemotherapy [4]. Bortezomib-based regimens showed better results and are therefore still the standard of care for NDMM patients in many countries [6-12]. Lenalidomide-based regimens can be an alternative [15], but it is not clear whether they are suitable for all transplant-ineligible NDMM patients, especially for those with highrisk cytogenetic aberrations $[15,16]$. Recent large randomised phase III trials showed that triplet regimens composed of bortezomib, lenalidomide and corticosteroids [17], or regimens with monoclonal antibodies can be much more effective [9]. However, this treatment is not yet widely available mostly for pharmaco-economical reasons. Therefore, bortezomib-based regimens are still the standard of care in many countries [18].

Our findings did not show any significant differences between treatment response, PFS, DOR and TTP in CVD and $C T D$ regimens in transplant-ineligible NDMM patients. The OS results were even better in the CTD group.

Our results are surprising since data from a meta-analysis of six large Eu- ropean randomised trials showed the superior effect of bortezomib over thalidomide. Patients treated with bortezomib-based combined protocols (bortezomib (Velcade ${ }^{\circledR}$ )-melphalanprednisone - VMP) achieved a significantly better response rate (ORR 78 vs. $69 \% ; p=0.01$ ), PFS rate (32.5 vs. 22.9 months; $\mathrm{p}=0.001)$ and $\mathrm{OS}$ rate (79.7 vs. 45.1 months, $p=0.008$ ) when compared to thalidomide-based treatment (melphalan-thalidomide-prednisone - MTP) [12].

Our CTD regimen treatment results are comparable to the Medical Research Council Myeloma IX randomised trial (ORR 63.8 vs. $60.6 \%$; PFS 13.0 vs. 10.3 months) [10]. It is obvious that in randomised trials, the MPT regimen has similar results to the CTD regimen $[4,10,19]$.

Our bortezomib treatment results are significantly worse than the VISTA trial results. In the VISTA trial, higher response rates (ORR 71 vs. 51\%) and survival intervals (TTP 24.4 vs. 15.2 months) were achieved [6].

The main reason for the difference between our results and those achieved by VISTA seems to be the length of treatment. In the VISTA trial, bortezomib was administered twice a week, i.e. on days
$1,4,8,11,22,25,29$ and 32 in cycles one to four; and weekly (day 1, 8, 22, 29) in cycles five to nine, so the treatment lasted 54 weeks. In our analysis, bortezomib was administered in a weekly dosing schedule, i.e. on days $1,8,15,22$, and the median of administered treatment cycles was four, which means only 16 weeks of treatment [6]. A similar situation was recorded in many other clinical trials $[9,11,12,19]$, where the treatment was much longer than in our analysis. The length of our treatment was clearly affected by 'stop rules' in treatment, established by Czech health insurance at the time of our treatment. Currently, it is not customary to administer just four cycles of treatment in transplant-ineligible NDMM patients.

In previously mentioned clinical trials, bortezomib was administered twice a week (intensive), instead of weekly (non-intensive) in our analysis. However, this fact does not seem crucial for the difference in our results. The issue of an intensive or non-intensive dosing effect on treatment results was described in an analysis published by Bringen et al. [20]. The results of this analysis showed that the efficiency of an intensive and a weekly schedule is comparable. Grade 3-4 polyneuropathy was significantly 
higher in patients with an intensive dosing schedule ( 28 vs. $8 \% ; p<0.001$ ) and leads to dose reduction in $41 \%$ of the patients and treatment withdrawal in 15\% of the patients. In the weekly-administration group, dose reduction was necessary in $17 \%$ of the patients and treatment was stopped in $5 \%$ of them. The cumulative dose of bortezomib was almost identical in both groups (39.4 vs. $40.1 \mathrm{mg} / \mathrm{m}^{2}$ ). Taken together, the $\mathrm{cu}-$ mulative dose has the main influence on efficiency but a higher frequency of bortezomib dosing correlates with higher toxicity. Toxicity, represented mainly by polyneuropathy leads to early dosing reduction or even treatment withdrawal [20].

We maintained a weekly bortezomib dosing schedule in all the patients in our analysis. As described above, the rationale for our dosing was better tolerance and a lower adverse event rate [20]. The bortezomib dose was reduced in $25 \%$ of the patients, and treatment was withdrawn in $10 \%$ of the patients due to toxicity, mostly represented by polyneuropathy. When compared with the previously mentioned analysis, we reduced the dosing or stopped treatment less frequently than in the intensive dosing schedule group. On the other hand, we reduced or stopped our treatment more frequently when compared to a once-a-week dosing schedule group, even in a lower number of treatment cycles (four vs. nine). We believe that early reduction was a key point of our feasible toxicity, lower than clinical trials $[6,11,12,16,19,20]$.

Subcutaneous bortezomib administration is the next precaution in the prevention of treatment-related polyneuropathy. In a phase III clinical trial, patients with subcutaneous bortezomib administration had a significantly lower incidence of polyneuropathy when compared to those with intravenous administration. Treatment efficiency was not significantly different [21]. On the other hand, Czech authors did not prove these results in a large retrospective analysis [7]. Subcutaneous administration was not allowed at the time of our patients' treatment, so all our patients obtained intravenous administration of bortezomib.
According to the previously mentioned toxicity management, polyneuropathy in the CVD group was significantly lower when compared to the CTD group. On the other hand, serious polyneuropathy (grade 2 and higher) was comparable in both groups. Other significantly different $A E$ rates between both groups were treatment-specific (i.e. constipation in the thalidomide group or mild thrombocytopenia in the bortezomib group). Serious (grade 3 and higher) haematologic or non-haematologic AEs were comparable between both groups.

In the phase II trial EVOLUTION, treatment with the CVD regimen achieved comparable results to the VMP regimen in the VISTA trial. ORR was very similar, $75 \%$ of the patients in the CVD arm achieved at least PR, compared to $71 \%$ of the patients treated with the VMP regimen in the VISTA trial. On the other hand, serious haematologic toxicities (grade 3 and greater) were lower in the cyclophosphamide regimens than in the oral melphalan regimens (neutropenia 30 vs. $40 \%$; thrombocytopenia 12 vs. $35 \%$; anaemia 0 vs. $19 \%)[6,22]$. According to our experience, there is a higher patient treatment adherence to daily oral cyclophosphamide administration than to sequential pulse oral melphalan, especially when a single daily melphalan dose is divided into more tablets.

Taken together, we found the bortezomib treatment length as a major reason for the difference between our results and those of VISTA in treatment response and survival intervals. Other treatment-related factors, such as dosing schedule or other drugs in the treatment protocol, seem to have no influence in our results of treatment response and previously mentioned survival intervals.

In a meta-analysis of six large European trials, a clear OS benefit of bortezomib-based treatment was described. More surprising are our better OS results in the thalidomide-based group. Similarly to other survival intervals, short bortezomib treatment length is probably the most important factor for such results. Other reasons could be the differences in the patients' ages, since the bortezomib group was significantly older.

Another possible reason for this treatment response or OS results may lie in the different representation of the free light chains (FLC) type of MM (BJ myeloma) in both treatment arms. The FLC type of MM is found approximately in $15 \%$ of all MM patients and it is connected to a worse prognosis in a new diagnosis $[23,24]$ or in a relapse [25]. In the CVD arm, FLC-type myeloma was present almost twice as often as in the standard population of MM patients.

Another reason for the differences between our results may be the unselected and non-randomised population in our group of patients. It is important to mention that in our real-life analysis, $10 \%$ of the patients were found to have an ECOG status of 3-4 at the time of diagnosis. Those patients would be excluded from most clinical trials.

\section{Conclusion}

Our analysis showed that short treatment with bortezomib has comparable response rates, PFS, TTP and DOR intervals to thalidomide treatment. The OS interval was even better in the thalidomide group. According to the clinical trial results, better outcomes of bortezomib treatment can be expected only after longer administration.

Differences in age or different representation of the BJ type of MM between both groups are not likely to be a key factor influencing our results.

In short treatment, serious AE rates were also comparable. Careful toxicity management (i.e. non-intensive dosing or early bortezomib dose reduction) led to lower rates of serious neuropathy when compared to the clinical trials.

Our work is an important analysis of NDMM patients' treatment outside of clinical trials. It clearly shows that if we want to achieve bortezomib efficiency, similarly to clinical trials, it is necessary to use bortezomib treatment long-term. If not, similar results as in thalidomide-based regimens can be expected.

\section{References}

1. Brozova L, Jarkovsky J, Pour L et al. Asymptomatic and treatment-requiring multiple myeloma - data from the 
Czech Registry of Monoclonal Gammopathies. Klin Onkol 2017; 30 (Suppl 2): 51-59. doi: 10.14735/amko20172S51.

2. Kumar SK, Rajkumar SV, Dispenzieri A et al. Improved survival in multiple myeloma and the impact of novel therapies. Blood 2008; 111(5): 2516-2520. doi: 10.1182/blood-2007-10-116129.

3. Singhal S, Mehta J, Desikan R et al. Antitumor activity of thalidomide in refractory multiple myeloma. N Engl J Med 1999; 341(21): 1565-1571. doi: 10.1056/NEJM199911183412102.

4. Fayers PM, Palumbo A, Hulin C et al. Thalidomide for previously untreated elderly patients with multiple myeloma: meta-analysis of 1685 individual patient data from 6 randomized clinical trials. Blood 2011; 118(5): 1239-1247. doi: 10.1182/blood-2011-03-341669.

5. Palumbo A, Waage A, Hulin C et al. Safety of thalidomide in newly diagnosed elderly myeloma patients: a meta-analysis of data from individual patients in six randomized trials. Haematologica 2013; 98(1): 87-94. doi: 10.3324/haematol.2012.067058.

6. San Miguel JF, Schlag R, Khuageva NK et al. Bortezomib plus melphalan and prednisone for initial treatment of multiple myeloma. N Engl J Med 2008; 359(9): 906-917. doi: 10.1056/NEJMoa0801479.

7. Minarik J, Pavlicek P, Pour L et al. Subcutaneous bortezomib in multiple myeloma patients induces similar therapeutic response rates as intravenous application but it does not reduce the incidence of peripheral neuropathy. PLoS One 2015; 10(4): e0123866. doi: 10.1371/journal.pone. 0123866 .

8. Usmani SZ, Crowley J, Hoering A et al. Improvement in long-term outcomes with successive total therapy trials for multiple myeloma: are patients now being cured? Leukemia 2012; 27(1): 226-232. doi: 10.1038/leu.2012.160.

9. Mateos MV, Dimopoulos MA, Cavo M et al. Daratumumab plus bortezomib, melphalan, and prednisone for untreated myeloma. N Engl J Med 2018; 378(6): 518-528. doi: 10.1056/NEJMoa1714678.

10. Morgan GJ, Davies FE, Gregory WM et al. Cyclophosphamide, thalidomide, and dexamethasone (CTD) as in - itial therapy for patients with multiple myeloma unsuitable for autologous transplantation. Blood 2011; 118(5): 1231-1238. doi: 10.1182/blood-2011-02-338665.

11. Sonneveld P, Goldschmidt H, Rosiñol L et al. Bortezomib-based versus nonbortezomib-based induction treatment before autologous stem-cell transplantation in patients with previously untreated multiple myeloma: a meta-analysis of phase III randomized, controlled trials. J Clin Oncol 2013; 31(26): 3279-3287. doi: 10.1200/JCO.2012.48.4626

12. Morabito F, Brighten S, Larocca A et al. Bortezomib, melphalan, prednisone (VMP) versus melphalan, prednisone, thalidomide (MPT) in eldery newly diagnosed multiple myeloma patients: a retrospective casematched study. Am J Hematol 2014; 89(4): 355-362. doi: 10.1002/ajh.23641.

13. Rajkumar SV, Dimopoulos MA, Palumbo A et al. International Myeloma Working Group updated criteria for the diagnosis of multiple myeloma. Lancet Oncol 2014 15(12): 538-548. doi: 10.1016/S1470-2045(14)70442-5

14. National Cancer Institute. Common Terminology Criteria for Adverse Events (CTCAE) v5.0. [online]. Available from: https://ctep.cancer.gov/protocolDevelopment/electronic applications/ctc.htm.

15. Rajkumar SV, Jacobus S, Callander NS et al. Lenalidomide plus high-dose dexamethasone versus lenalidomide plus low-dose dexamethasone for newly diagnosed multiple myeloma: an open-label randomised controlled trial. Lancet Oncol 2010; 11(1): 29-37. doi: 10.1016/S14702045(09)70284-0.

16. Reece D, Song KW, Roland B et al. Influence of cytogenetics in patients with relapsed or refractory multiple myeloma treated with lenalidomide plus dexamethasone: adverse effect of deletion 17p13. Blood 2009; 114(3): 522-525. doi: 10.1182/blood-2008-12-193458.

17. Durie BG, Hoering A, Abidi MH et al. Bortezomib with lenalidomide and dexamethasone versus lenalidomide and dexamethasone alone in patients with newly diagnosed myeloma without intent for immediate autologous stem-cell transplant (SWOG S0777): a randomised, open- label, phase 3 trial. Lancet 2017; 389(10068): 519-527. doi: 10.1016/S0140-6736(16)31594-X.

18. Raab MS, Cavo M, Delforge M et al. Multiple myeloma: practice patterns across Europe. Br J Haematol 2016; 175(1): 66-76. doi: 10.1111/bjh.14193.

19. Mateos MV, Oriol A, Martínez-López J et al. Bortezomib, melphalan, and prednisone versus bortezomib, thalidomide, and prednisone as induction therapy followed by maintenance treatment with bortezomib and thalidomide versus bortezomib and prednisone in elderly patients with untreated multiple myeloma: a randomised trial. Lancet Oncol 2010; 11(10): 934-941. doi: 10.1016/S1470-2045(10)70187-X.

20. Bringhen S, Larocca A, Rossi D et al. Efficacy and safety of once-weekly bortezomib in multiple myeloma patients. Blood 2010; 116(23): 4745-4753. doi: 10.1182/blood-2010-07-294983.

21. Moreau P, Pylypenko H et al. Subcutaneous versus intravenous administration of bortezomib in patients with relapsed multiple myeloma: a randomised, phase 3, noninferiority study. Lancet Oncol 2011; 12(5): 431-440. doi: 10.1016/S1470-2045(11)70081-X.

22. Kumar S, Flinn I, Richardson PG et al. Randomized, multicenter, phase 2 study (EVOLUTION) of combinations of bortezomib, dexamethasone, cyclophosphamide, and lenalidomide in previously untreated multiple myeloma. Blood 2012; 119(19): 4375-4382. doi: 10.1182/blood2011-11-395749.

23. Rafae A, Malik MN, Abu Zar M et al. An overview of light chain multiple myeloma: clinical characteristics and rarities, management strategies, and disease monitoring. Cureus 2018; 10(8): e3148. doi: 10.7759/cureus.3148.

24. Zhang JJ, Sun WJ, Huang ZX et al. Light chain multiple myeloma, clinic features, responses to therapy and survival in a long-term study. World J Surg Oncol 2014; 12: 234. doi: 10.1186/1477-7819-12-234.

25. Caillon H, Attal M, Avet-Loiseau $\mathrm{H}$ et al. Free light chain escape in multiple myeloma: an exceptional phenomenon. Blood 2016; 128(22): 4428. doi: 10.1182/blood. V128.22.4428.4428.

\section{Společnost Merck Sharp \& Dohme s.r.o. se stala partnerem České onkologické společnosti ČLS JEP pro rok 2019.}

